IJAMSR 3 (5) www.ijamsr.com CrossRef: https://doi.org/10.31426/ijamsr.2020.3.5.3312

\title{
Psychological Study On Children Facing Health Challenges Due To Affluenza In Iran
}

\author{
Zeynab Binandeh \\ Graduate, Research Sciences Department of Azad University of Urmia, Iran \\ Email: binandehzeynab@gmail.com
}

Keywords:

Affluenza,

Happiness,

Gender,

Youth

A B S T RA C T

Affluenza happens when people are in quest for money, riches, and material belonging to the detriment of different wellsprings of self-esteem and contentment. It has arrived at epidemic extents and has created numerous symptoms detrimental to our kids' social and emotional development. The current examination aimed to consider the impact of Affluenza on Happiness of youthful understudies. It was theorized that I) Affluent youth will score low on bliss as compared to non-affluent youth, ii) Affluent females will have higher joy level as compared to affluent males. Investigation of difference uncovered that affluent and nonaffluent differed significantly $\left(\mathrm{F}=709.54^{* *}\right)$ on satisfaction levels. Results likewise uncovered significant sex differences $\left(\mathrm{F}=19.58^{* *}\right)$ in joy levels of affluent members. Females scored much higher $(\mathrm{M}=3.97)$ on joy scale in comparison to males $(\mathrm{M}=3.08)$.

Citation: Zeynab Binandeh (2020). Psychological Study On Children Facing Health Challenges Due To Affluenza In Iran. International Journal of Advanced Multidisciplinary Scientific Research (IJAMSR) ISSN:2581-4281, 3 (5), May 2020, Pp 12 - 22 
IJAMSR 3 (5) www.ijamsr.com CrossRef: https://doi.org/10.31426/ijamsr.2020.3.5.3312

\section{J A M S R}

\section{International Journal of \\ Advanced Multidisciplinary Scientific Research (IJAMSR) ISSN:2581-4281}

\section{Introduction}

Affluenza causes ailment since it forestalls the meeting of genuine mental needs, conflating them with needs confected by promoters and consumerism. The most ideal approach to combat Affluenza is to learn in a profound, masterful, individual route with regards to how to really appreciate and find meaning in life. We seldom ask ourselves that what makes our lives meaningful. Studies have thought about that there is a quantitative connection between individuals' emotional experience and their optimal functioning. Studies show that accomplishment relies upon vitality. The higher the vitality, the more prominent will be the limit with respect to accomplishment. Vitality is a statement of will. Will relies upon goal. The higher our yearnings, the more prominent the vitality we produce as a part of our character.

Be that as it may, more an individual matures mentally; the more one sets its own difficulties as opposed to trusting that life will do it for us. By reacting to difficulties, people make their outer life a cognizant means for their mental advancement. They develop by changing over difficulties into circumstances, while offering importance to their worth system. The higher the qualities that an individual can communicate in activities, the more they develop in limit with regards to work and limit with respect to individual fulfilment. It very well may be accomplished by getting more prominent information on oneself, all things considered of extraordinary worth since it encourages people to trust in their unutilized limits and makes them mindful of the manners by which one can improve us.

Therefore, the main aim of this examine is to make a comparison between social, social and mental problems of older individuals of two Bakhtiari and Baluch ethnic gatherings in Iran. To understand this main aim, some auxiliary aims must be considered which are as follows: 1) defining social problems and issues confronting Youngsters; 2) laying out physical problems and issues confronting Youngsters; 3) clarifying social problems and issues facing Youngsters; 4) portraying mental problems confronting Youngsters; 5) Giving scientific answers for physical, socio social and mental problems confronting Youngsters in Baluch and Bakhtiari ethnic gatherings in Iran. 
IJAMSR 3 (5) www.ijamsr.com CrossRef: https://doi.org/10.31426/ijamsr.2020.3.5.3312

\section{J A M S R}

\section{International Journal of \\ Advanced Multidisciplinary Scientific Research (IJAMSR) ISSN:2581-4281}

\section{LITERATURE REVIEW}

Levy et al. (2010) in this article "Adjustment attributes of sound kin of youngsters with autism". Compared parents ${ }^{\text {ee }}$ self-reports with self-reports from twenty seven kids who have kin with autism and twenty seven youngsters with no impaired kin. Guardians were approached to give an account of the kid conduct agenda and complete a Weinberger Adjustment Inventory so as to survey their own record of their social and emotional adjustment.

Mohammad Movahedi (2009) in this article they investigation the wellbeing status of the country regions in Iran. Wellbeing status had improved in rustic territories of Iran as of late, despite the fact that imbalance between areas remains an important medical issue. So they recommend by utilizing the progressed measurable models could be utilized to foresee the patterns of wellbeing markers for future years and help the wellbeing system to set its objectives more soundly in the country territories of Iran.
Ann Graves (2009) made an attempt to identify the requirement for systems to improve access to social insurance administrations and to help improvement of wellbeing outcomes in the United States. Since to expand the personal satisfaction and to eliminate wellbeing differences (Social and policy centered issues) in human services access and wellbeing outcomes. $\mathrm{He}$ additionally utilizes the Andersen Behavioural model for wellbeing administrations it gives one way to deal with access to wellbeing administrations.

\section{Ashley Clark (2015) Concerns viewing} affluenza as a pestilence have been discreetly brought up in a sociological setting and to a great extent overlooked in standard society for quite a few years. At the point when the possibility of affluenza was brought up in the criminal court system by the safeguard's assessing analyst during a prominent murder case, nonetheless, the worries with respect to impacts of affluenza rose to the cutting edge. Actually, the preliminary of Ethan Couch, result of rich guardians, caused open objection when an affluenza protection was noted as a potential supporter of an apparently tolerant sentence. This paper gives a concise diagram 
IJAMSR 3 (5) www.ijamsr.com CrossRef: https://doi.org/10.31426/ijamsr.2020.3.5.3312

\section{J A M S R}

\section{International Journal of \\ Advanced Multidisciplinary Scientific Research (IJAMSR) ISSN:2581-4281}

of the history and advancement of the affluenza idea, assesses the effect of affluenza through a systemic focal point, surveys systemic impacts in court decisions, talks about the potential effect of advocates' jobs in the court, and gives a case delineation to exhibit this potential.

\section{Vandad Sharifi, Ramin Mojtabai, Zahra} Shahrivar, Javad Alaghband-Rad, Hadi Zarafshan, Lawrence Wissow (2016) the requirement for emotional wellness care among kids and young people in Iran, as in other low and centre pay nations (LAMIC) remains generally neglected. In this paper, we tried to give a diagram of the degree of neglected need and psychological well-being administrations in Iran. We additionally intended to propose ways to deal with address this hole. We audited the distributed epidemiologic investigations of kid and preadult mental and conduct health issues in Iran.

\section{Suniya S. Luthar (2018) Experiencing} childhood in the culture of affluence can indicate different psychosocial dangers. Studies have indicated that high society youngsters can show raised disturbance in a few regions, for example, substance use, tension, and despondency and that two arrangements of elements appear to be embroiled, that is, exorbitant weights to accomplish and disconnection from guardians (both exacting and enthusiastic). While characteristically, princely youth and poor youth are separately thought of as being at "generally safe" and "high hazard," near investigations have uncovered a larger number of likenesses than contrasts in their modification examples and socialization processes. In the years ahead, therapists must address the long-standing disregard of a gathering of youths rewarded, up to this point, as not requiring their consideration. Family riches doesn't naturally present either wisdom in parenting or equanimity of soul; though youngsters rendered atypical by ideals of their folks' riches are without a doubt special in numerous regards, there is additionally, plainly, the potential for some nontrivial dangers to their psychological prosperity.

\section{METHODOLOGY}

Sample: The sample for the current investigation comprised of 400 youthful grown-ups chose from different universities and departments in Iran. An aggregate of 76 
IJAMSR 3 (5) www.ijamsr.com CrossRef: https://doi.org/10.31426/ijamsr.2020.3.5.3312

\section{J A M S R}

\section{International Journal of \\ Advanced Multidisciplinary Scientific Research (IJAMSR) ISSN:2581-4281}

623 subjects between the ages of 18 and 24 years, with the mean period of 21 years, were drawn nearer. Assent of the particular school Principals, Head of the departments and subjects were taken ahead of time. Post administering Affluenza scale on 623 subjects, 200 males (Affluent and Non-Affluent) and 200 females (Affluent and Non Affluent) were screened out. Accidental sampling was utilized for data collection.

Research Design: To break down the impact of autonomous factors, namely, Affluenza on subordinate variable, for example Psychological Growth and Happiness, 2X2 Analysis of Variance (ANOVA) was applied. Experimental-Control Pre-Post configuration was utilized to evaluate the efficacy of CBT on satisfaction and psychological growth.

\section{ANALYSIS \& RESULT}

In the light of expressed speculations, means, standard deviations and examination of change were computed. To see the effect of two degrees of Affluenza (Affluent and Non Affluent) and two degrees of Gender (Males and Females) on Happiness and Psychological growth, the data was prepared utilizing $2 \times 2$ Analysis of Variance,. To examine the effect of intellectual conduct treatment on bliss and psychological growth activities of affluent subjects, the data are exposed to ANOVA and MANOVA. The data were tried for homogeneity of difference before exposing to Analysis of Variance. The Hartley test demonstrated that the assumption of homogeneity of difference was maintained. For the motivation behind examination of the data, the Statistical Package for Social Sciences rendition 13.0 was utilized. The outcomes are depicted in an even form in Table No.1 to Table No.8. Graphical portrayals of the findings are delineated in Figures 1 to 2.

\section{Table 1: Bifurcation of number of} participants in Part I

\begin{tabular}{|l|c|c|c|}
\hline Category & \multicolumn{1}{|c|}{$\begin{array}{c}\text { No. of } \\
\text { individuals }\end{array}$} & Male & Females \\
\hline Total sample & \multicolumn{3}{|c|}{623} \\
\hline $\begin{array}{l}\text { Affluent } \\
\text { (who scored >30 on } \\
\text { Affluenza Scale) }\end{array}$ & 200 & 100 & 100 \\
\hline $\begin{array}{l}\text { Non-Affluent } \\
\text { (who scored <19 on } \\
\text { Affluenza Scale) }\end{array}$ & 200 & 100 & 100 \\
\hline $\begin{array}{l}\text { Total in Part I } \\
\text { Excluded (who scored } \\
\text { between 20-30 on } \\
\text { Affluenza Scale) }\end{array}$ & & 200 & 200 \\
\hline
\end{tabular}


IJAMSR 3 (5) www.ijamsr.com CrossRef: https://doi.org/10.31426/ijamsr.2020.3.5.3312

\section{J A M S R}

\section{International Journal of \\ Advanced Multidisciplinary Scientific Research (IJAMSR) ISSN:2581-4281}

Table 1 presents number of members partitioned into different classes. As appeared, there were complete 623 members. Out of these, data of 400 people was finally chosen to examine the outcomes. Among these 400 people, 100 males who scored high on affluenza were set in the Male Affluent classification, 100 people were Non-Affluent Males, who scored low on Affluenza, 100 females, who scored high on affluenza, were identified as Affluent Females, and 100 females who scored low on affluenza, were arranged as Non-Affluent Females. 223 people were excluded from the examination as they scored normal on affluenza.

Table 2: Comparison of Means, SDs and Fratios for PGIS scores in relation to Gender and Affluenza

\begin{tabular}{|l|l|l|l|l|}
\hline Variables Levels & Means & Sd & F-Ratio \\
\hline Gender & Males & 29.28 & 5.59 & $19.52^{* *}$ \\
\cline { 2 - 4 } & Females & 31.75 & 5.60 & \\
\hline Affluenza & Affluent & 21.74 & 5.81 & $981.14^{* *}$ \\
\cline { 2 - 4 } & $\begin{array}{l}\text { Non- } \\
\text { Affluent }\end{array}$ & 39.29 & 5.38 & \\
& & & \\
\hline
\end{tabular}

Table No. 2 shows Means, Standard Deviations alongside F-proportions for self-improvement activities as a function of Affluenza and Gender. As appeared, Affluent scored low on self-improvement activities $(\mathrm{M}=21.74, \mathrm{SD}=$ $5.81)$ as compared to non-affluent $(\mathrm{M}=39.29$, $\mathrm{SD}=5.38)$. The difference between these two gatherings was found to be measurably significant $\{\mathrm{F}(1,396)=981.14, \mathrm{p}<0.01\}$, which implied that people high on affluenza were found to have less self-improvement than the individuals who were low on affluenza. These findings bolster the first theory that nonaffluent would score higher on selfimprovement activity scale as compared to affluent. It can likewise be seen from Table No. 2 that females scored higher on selfawareness $(\mathrm{M}=31.75, \mathrm{SD}=5.60)$ as compared to males $(M=29.28, S D=5.59)$. Significant difference was found in the two gatherings $\{\mathrm{F}$ $(1,396)=19.52, p<.01\}$. This shows females were higher on self-improvement activities in comparison to males. These outcomes prompted the acknowledgment of second theory that females would score higher on selfimprovement activities as compared to males. 
IJAMSR 3 (5) www.ijamsr.com CrossRef: https://doi.org/10.31426/ijamsr.2020.3.5.3312

Table 3: ANOVA Summary for the effect of Gender and Affluenza on PGIS

\begin{tabular}{|l|c|c|c|c|}
\hline $\begin{array}{l}\text { Source of } \\
\text { Variation }\end{array}$ & SS & DF & MS & F \\
\hline Gender (A) & 612.56 & 1.00 & 612.56 & $19.52^{* *}$ \\
\hline $\begin{array}{l}\text { Affluenza } \\
\text { (B) }\end{array}$ & 30782.70 & 1.00 & 30782.70 & $981.14^{* *}$ \\
\hline AB & 254.40 & 1.00 & 254.40 & $8.11^{* *}$ \\
\hline Error & 12424.27396 .00 & 31.37 & \\
\hline
\end{tabular}

Table 4: Means of PGIS scores showing interaction of Gender and Affluenza.

\begin{tabular}{|l|l|c|c|}
\hline \multicolumn{2}{|l|}{ Comparison groups } & \multicolumn{2}{c|}{ GENDER } \\
\cline { 3 - 4 } \multicolumn{2}{|l}{} & MALES & FEMALES \\
\hline \multirow{2}{*}{ Affluenza } & AFFLUENT & 21.30 & 22.18 \\
\cline { 2 - 4 } & $\begin{array}{l}\text { NON- } \\
\text { AFFLUENT }\end{array}$ & 37.25 & 41.32 \\
& & \\
\hline
\end{tabular}

Table No. 3 speaks to ANOVA summary for self-awareness activities as a function of Affluenza and sex. As given in Table No. 3 that other than the main effect of Gender and Affluenza, the connection between both the factors for example affluenza and sexual orientation was sufficient to reach to the significant level $\{\mathrm{F}(1,396)=8.11, \mathrm{p}<.01\}$.

Table No. 4 shows the mean scores of selfimprovement activities indicating collaboration of Gender and Affluenza which uncovered that affluenza was making difference in males and females. This pattern could likewise be seen in Figure 1. Self-improvement activity scores differ significantly in both the degrees of affluenza and sexual orientation.

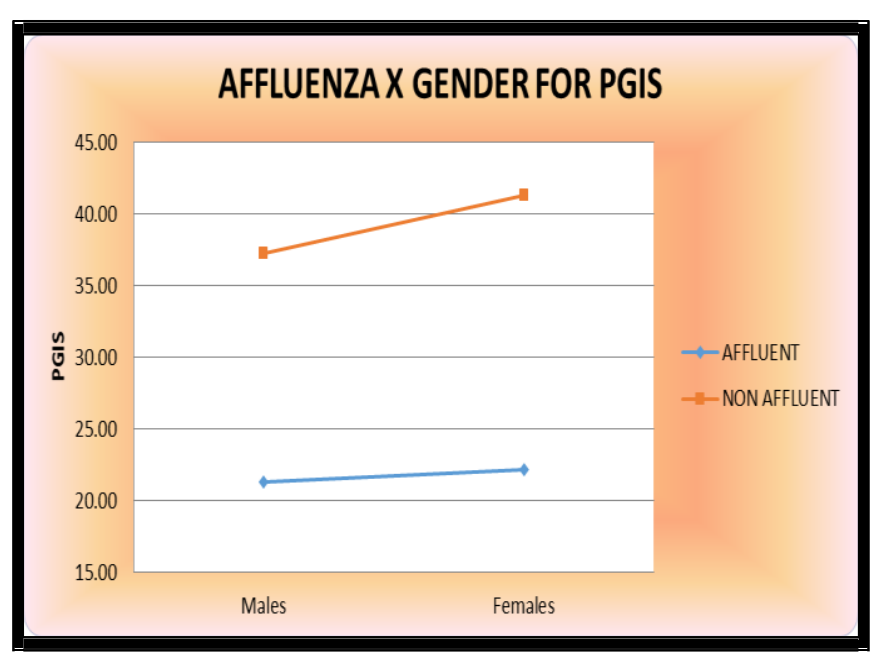

Figure 1: Graphical representation of Means of PGIS scores showing interaction of Gender and Affluenza 
IJAMSR 3 (5) www.ijamsr.com CrossRef: https://doi.org/10.31426/ijamsr.2020.3.5.3312

Table 5: Summary of Simple effects of Gender on Affluent and non-affluent individuals for PGIS scores

\begin{tabular}{|c|c|c|c|c|}
\hline \begin{tabular}{|l|} 
Source of \\
Variation
\end{tabular} & SS & DF & MS & F-ratio \\
\hline $\begin{array}{|ll|}\text { A } & \text { FOR } \\
\text { B1 } & \\
\end{array}$ & 38.72 & 1.00 & 38.72 & $1.23 \mathrm{~ns}$ \\
\hline $\begin{array}{|ll|}\text { A } & \text { FOR } \\
\text { B2 } & \\
\end{array}$ & 828.25 & 1.00 & 828.25 & $26.40 * *$ \\
\hline Error & 12424.2 & 396.00 & 31.37 & \\
\hline
\end{tabular}

In Table No. 5, the outline of investigation of change for the basic impacts of A (Gender) on factor B has been introduced. It has been seen that straightforward impact of $\mathrm{A}$ for level b1 isn't noteworthy $\{\mathrm{F}(1,396)=1.23 \mathrm{~ns}\}$, showing that guys and females in non-princely class don't vary essentially on self-improvement activities. Be that as it may, the watched value of $\mathrm{F}$ in regard to basic impact of $\mathrm{A}$ for level $\mathrm{b} 2$ far surpass the basic value $\{\mathrm{F}(1,396)=26.40$, $\mathrm{p}<.01\}$, which implies that Affluenza essentially impacts self-improvement commencement. For rich level (b2), the selfimprovement activity scores are seen as better for females in contrast with guys showing better self-awareness of females in contrast with males.
Table 6: Summary of Simple effects of Affluenza of Males and Females for PGIS scores

\begin{tabular}{|c|c|c|c|c|}
\hline $\begin{array}{l}\text { Source of } \\
\text { Variation }\end{array}$ & SS & DF & MS & F-ratio \\
\hline \begin{tabular}{|ll} 
B & FOR \\
A1 & \\
\end{tabular} & 12720.13 & 1.00 & 12720.13 & $405.43^{*}$ \\
\hline \begin{tabular}{|ll} 
B & FOR \\
A2 &
\end{tabular} & 18316.98 & 1.00 & 18316.98 & $583.82 *=$ \\
\hline Error & 12424.27 & 396.00 & 31.37 & \\
\hline
\end{tabular}

Table No. 6 presents the outline of analysis of difference for the basic impacts of $B$ (Affluenza) on factor A. It has been demonstrated that the watched value of $F$ in regard to straightforward impact of B for level $\mathrm{A} 1\{\mathrm{~F}(1,396)=405.43, \mathrm{p}<.01\}$ and $\mathrm{A} 2\{\mathrm{~F}$ $(1,396)=583.82, \mathrm{p}<.01\}$ far surpasses the basic value. This implies for both the degrees of sex (A1\& A2), the self-awareness activity scores are better for non-wealthy females and guys in contrast with rich females and guys. Non well-off demonstrated preferred mental development over wealthy people. 
IJAMSR 3 (5) www.ijamsr.com CrossRef: https://doi.org/10.31426/ijamsr.2020.3.5.3312

\section{International Journal of Advanced Multidisciplinary Scientific Research (IJAMSR) ISSN:2581-4281}

Table 7: Comparison of Means, SDs and Fratios for Happiness scores in relation to Gender and Affluenza

\begin{tabular}{|l|c|c|c|c|}
\hline Variables & Levels & Means & SD & F-Ratio \\
\hline Gender & Males & 3.08 & 0.89 & $19.58^{* *}$ \\
\cline { 2 - 4 } & Females & 3.47 & 0.87 & \\
\hline Affluenza & Affluent & 2.10 & 0.76 & $709.54 * *$ \\
\cline { 2 - 4 } & $\begin{array}{c}\text { Non- } \\
\text { Affluent }\end{array}$ & 4.46 & 0.99 & \\
\hline
\end{tabular}

Table No.7 shows Means, Standard Deviations of satisfaction corresponding to Affluenza and sexual orientation alongside F-proportions. As delineated, females scored higher on bliss $(\mathrm{M}=3.47, \mathrm{SD}=0.87)$ when contrasted with guys $(\mathrm{M}=3.08, \mathrm{SD}=0.89)$. The distinction between these two gatherings was seen as measurably noteworthy $\{\mathrm{F}=19.58, \mathrm{p}<0.01\}$, which inferred that females were seen as more joyful than guys. Further, noteworthy contrast has been found between the individuals who were high and low on Affluenza $(\mathrm{F}=709.54, \mathrm{P}<.01)$. As appeared, well-off people scored low on satisfaction level $(\mathrm{M}=2.10, \mathrm{SD}=0.76)$ when contrasted with non-well-off people $(\mathrm{M}=4.46$, $\mathrm{SD}=0.99)$.
Table 8: ANOVA Summary for the effect of Gender and Affluenza on Happiness scores

\begin{tabular}{|l|c|c|c|c|}
\hline $\begin{array}{l}\text { Source of } \\
\text { Variation }\end{array}$ & SS & DF & MS & F \\
\hline GENDER (A) & 15.41 & 1.00 & 15.41 & $19.58^{* *}$ \\
\hline $\begin{array}{l}\text { AFFLUENZA } \\
\text { (B) }\end{array}$ & 558.14 & 1.00 & 558.14 & $709.54 * *$ \\
\hline AB & 2.18 & 1.00 & 2.18 & $2.77 \mathrm{~ns}$ \\
\hline Error & 311.50 & 396.00 & 0.79 & \\
\hline
\end{tabular}

Table 9: Means of Happiness scores showing interaction of Gender and Affluenza

\begin{tabular}{|l|l|l|l|}
\hline \multicolumn{2}{|l|}{ Comparison groups } & Gender \\
\hline \multicolumn{1}{|l}{} & MALES & FEMALES \\
\hline Affluenza & AFFLUENT & 1.83 & 2.37 \\
\cline { 2 - 4 } & $\begin{array}{l}\text { NON- } \\
\text { AFFLUENT }\end{array}$ & 4.34 & 4.58 \\
\hline
\end{tabular}

Table No. 8 speaks to ANOVA rundown for Happiness as an element of Affluenza and Gender. In spite of the fact that the fundamental impact of both Affluenza and Gender came out to be huge for joy, yet the cooperation impact of Affluenza with Gender didn't arrive at the criticalness level $\{\mathrm{F}(1,396)$ $=2.77$, ns $\}$. Same finding is introduced in Table No. 9 and Figure 2 which shows mean scores of bliss acquired independently by 
IJAMSR 3 (5) www.ijamsr.com CrossRef: https://doi.org/10.31426/ijamsr.2020.3.5.3312

\section{J A M S R}

\section{International Journal of \\ Advanced Multidisciplinary Scientific Research (IJAMSR) ISSN:2581-4281}

males and females in affluent and non-affluent class.

FIGURE 2: Graphical representation of Means of Happiness scores showing interaction of Gender and Affluenza

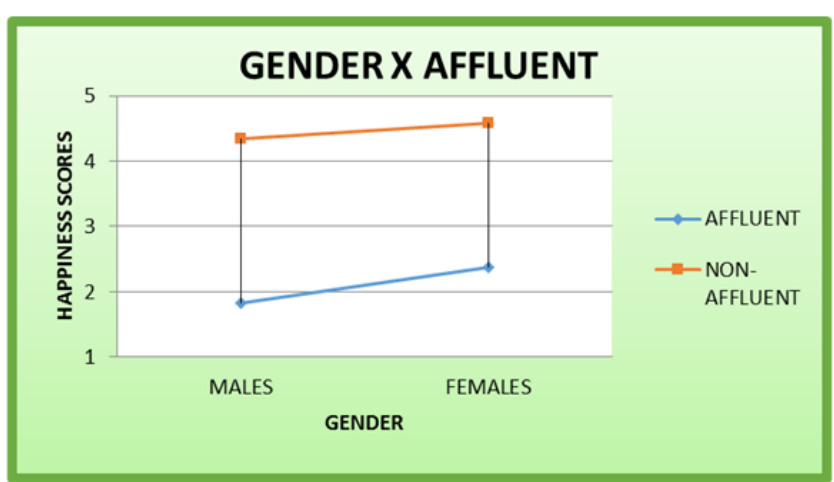

\section{CONCLUSION}

However, very little has been examined on affluenza, yet it is recognized that affluenza is becoming common and on occasion a significant problem. Pursuing money to achieve satisfaction and joy in life mostly winds up in a condition of psychological imbalance, misshaped reality and false impression of self. Affluenza gives off an impression of being a self-defeating standard of conduct marked by transient benefits and long-haul costs. Such long-haul cost of affluenza for example low satisfaction level and poor psychological growth were explored in the current research work. This examination aimed to comprehend the impact of affluenza on bliss and psychological growth among Indian youth matured 18 to 24 . The reason for the investigation was to evaluate the differences among affluent and non-affluent on bliss and psychological growth of youthful males and females, just as, to apply CBT to restore the mind-set of the individuals who have affluent proclivity by empowering the limit with regards to optimal functioning in psychological and social domains, and upgrading individual and relational qualities, for example, social competencies, emotional knowledge, maturity and adapting procedures. 
IJAMSR 3 (5) www.ijamsr.com CrossRef: https://doi.org/10.31426/ijamsr.2020.3.5.3312

\section{References}

1) Titelman, P. (2018). Clinical applications of Bowen systems family therapy. New York, NY: Routledge. Rohrbaugh, J. B. (2008) Comprehensive guide to child custody evaluations: Mentalhealth and legal perspectives. New York, NY: Springer.

2) deGraaf, J., Wann, D., \& Naylor, T. H. (2014). Affluenza: How overconsumption iskilling us-and how to fight back (3rd ed.). San Francisco, CA: Berrett-Koehler.Forester-Miller, H., \& Davis, T. (1996). A practitioner's guide to ethical decision

3) Morelen, D., \& Shaffer, A. (2012). Understanding clinical, legal, and ethical issues inchild emotional maltreatment. Journal of Aggression Maltreatment \& Trauma,21(2), 188201.

doi:10.1080/10926771.2012.639054

4) Watkins, J. (2014, February 6). Lawyer blasts media for focus on "affluenza" defense. Retrieved from http://www.cnn.com/2014/02/06/justice /texas-affluenza/index.html

5) Baker, A.M.; Moschis, G.P.; Ong, F.S.; Attanapanyasat, R. (2013). Materialism and Life Satisfaction: The Role of Stress and Religiosity. The Journal of Consumer Affairs, p. 548-563.
6) Bredehoft, D. J., Mennicke, S. A., Potter, A. M., \& Clarke, J. I. Perceptions attributed by adults to parental overindulgence during childhood. Journal of Family and Consumer Sciences Education, 2018, 16(2), 3-17.

7) Oxford University Press. Definition of Affluenza. Retrieved August 24, 2018, from https://en.oxforddictionaries.com/ definition/affluenza

8) Abedi, M. R., \& Vostanis, P. (2010). Evaluation of quality of life therapy for parents of children with obsessivecompulsive disorders in Iran. European Child and Adolescent Psychiatry, 19(7), 605-613. doi:10.1007/s00787-0100098-4.

9) Mokhtari, F. and Ghasemi, N. (2011). Comparison of elderly quality of life and mental health living in nursing homes and members of retired of Shiraz city. Salmand: Iranian J. Ageing., 5: 53 63.

10) Sharifi, Vandad \& Mojtabai, Ramin \& Shahrivar, Zahra \& Alaghband Rad, Javad \& Zarafshan, Hadi \& Wissow, Lawrence. (2016). Child and Adolescent Mental Health Care in Iran: Current Status and Future Directions. Archives of Iranian medicine. 19. 797804. 